Physical Therapy Journal of Indonesia (PTJI) 2021, Volume 2, Number 1: 16-19

E-ISSN : 2722-6034; P-ISSN : 2722-0125

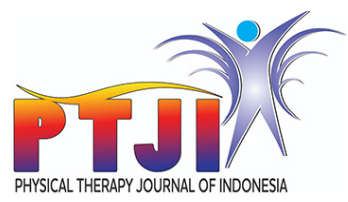

\title{
Exercises with A Target Heart Rate both Safety and Effectiveness for Reducing Sedentary Effects During Pandemic of Covid-19
}

\author{
Anak Agung Gede Eka Septian Utama ${ }^{1 *}$, M. Widnyana ${ }^{1}$, I Putu Yudi Pramana ${ }^{1}$
}

\begin{abstract}
Introduction: Limited activities will increase the risk of sedentary activity, so that it will become a new problem. Exercise is an effort to reduce sedentary activity and reduce boredom, maintain health, and increase the immune system. The right kind of exercise will have a good and bad impact. Therefore, this study aims to look at exercise with a target heart rate, safety and effectiveness, and reduce sedentary effects during the Covid-19 pandemic.

Methods: The data used has been through literature studies obtained from research articles including PubMed, ScienceDirect, and Google Scholar. With keywords, including COVID-19 pandemic, sedentary effects, exercise, target heart rate. The data analysis technique used is argumentative, descriptive analysis.
\end{abstract}

Results: Based on the literature view, the writer found ten related articles. This study provides evidence of the effect of exercise with target heart rate both safety and effectiveness for reducing sedentary effect. This article explained that it knows the exercise heart rate that the heart wants to reach and can be accepted by the heart, reduces lipid, increases the immune response, improves fitness and heart health.

Conclusion: Exercises can use the target heart rate to provide an overview of the range of training zones you want to achieve and provide safety and effectiveness in exercising, especially the cardiovascular system.
'Department of Physical Therapy, College of Medicine, Universitas Udayana, Bali, Indonesia

*Corresponding author: Anak Agung Gede Eka Septian Utama, Department of Physical Therapy, College of Medicine, Universitas Udayana, Bali, Indonesia; gungeka24@yahoo.com

Received : 2021-02-26 Accepted : 2021-04-24 Published: 2021-05-12

Keywords: Covid-19 pandemic, exercise, safety, sedentary lifestyle, target heart rate.

Cite this Article: Utama, A.A.G.S., Widnyana, M., Pramana, I.P.Y. 2021. Exercises with A Target Heart Rate both Safety and Effectiveness for Reducing Sedentary Effects During Pandemic of Covid-19. Physical Therapy Journal of Indonesia 2(1): 16-19. D0I: 10.51559/ptji.v2i1.20

\section{INTRODUCTION}

Since it was first reported in Wuhan, China, the coronavirus disease 2019 (Covid-19) ${ }^{1}$ and declared a pandemic by the world health organization (WHO) due to spreading around the world and causing high morbidity and mortality. ${ }^{2}$ Indonesia reported its first case of COVID-19 in March 2020, which was transmitted from person to person. The steps taken to prevent this virus are by applying clean living, social distancing, wearing masks and maintaining distance. ${ }^{3}$

The Covid-19 pandemic has caused restrictions on community activities such as studying, working, worshipping and sports. This limitation is useful in preventing the spread of the Covid-19. Still, on the other hand, it will also cause boredom, stress, sedentary activity. It can even reduce health status. ${ }^{4}$ With no certainty about when this pandemic will end, and the absence of medicine has caused people to start experiencing boredom and sedentary lifestyles.

A sedentary lifestyle is a habit of someone who doesn't do much physical activity or doesn't do much movement. Sedentary behaviour such as the use of electronic equipment (TV, laptop, videogame, cellphone) in the room occurs at a sophisticated time like now, and this can be related to health risks. ${ }^{5}$ The effects of these habits can include obesity, cardiovascular and metabolic diseases, cancer, and psychosocial problems.6 Recent evidence suggests that the sedentary lifestyle directly affects metabolism, bone mineral content, and vascular health. ${ }^{6}$

Exercise is a choice to prevent boredom, stress, sedentary activities, improve health status and increase body immunity. WHO explained that exercise is an inexpensive way to maintain health, improve fitness, self-confidence, psychosocial, sleep quality, and reduce alcohol dependence. ${ }^{7}$ During the Covid-19 pandemic, people must carry out sports carefully. Most people consider moderate exercise to be sufficient without seeing good exercise procedures. ${ }^{8}$ If exercise is done inappropriately and excessively, it will harm the body; for example, it can cause fatigue and injury. ${ }^{9}$

In general, exercise should be carried out regularly, with the right duration, intensity and type. The body can measure and react to stress more effectively during exercise and increases the fight or flight stress response that improves the body's response to stress. ${ }^{10}$ The benefits of exercise with a 
Target Heart Rate (THR) are that you can exercise more efficiently and be more goal-oriented. The THR concept evaluates a person's pulse rate and cardiovascular ability to perform physical activity to provide a safe exercise zone, and the desired sports goals are achieved. ${ }^{11}$

Based on the explanation mentioned above, this literature study aims to find out information about an exercise with a THR that effectively reduces sedentary effects during the COVID-19 pandemic.

\section{METHODS}

The data source used in this study was valid and justified research articles. The type of data used was quantitative and qualitative. The data used has been through literature studies obtained from research articles including PubMed, ScienceDirect, and Google Scholar. The data that has been collected will be processed systematically and logically. We use the keywords Covid-19 pandemic, sedentary effects, exercise, target heart rate. The data analysis technique used was argumentative, descriptive analysis.

\section{RESULTS}

There are several articles that had been reviewed to prove that exercise with a target heart rate both safety and effectiveness reducing sedentary effects during the Covid-19 pandemic. The study from Zheng et al (2020) ${ }^{12}$ during the Covid-19 pandemic caused a decrease in physical activity, an increase in sedentary behavior, and an increase in long sleep duration which will have implications for health, especially the sedentary effect. Another study also found that long periods of sedentary behaviour with no breaks, which has a negative effect on health outcomes. ${ }^{13}$ During the Covid-19 pandemic, interventions that increase physical activity while decreasing sedentary behaviour in young adults are needed, particularly for individuals who have prolonged sitting habit for working or watching movies. ${ }^{14}$ Simple home workouts, such as body strength training or high-intensity interval training (HIIT), may be used to help this group.

The study conducted by Hamburg et al. (2007) $)^{15}$ suggests that prolonged periods of persistent behaviour can dramatically increase the risk of metabolic disease. This finding is corroborated by Bauman and Spungen (2008) ${ }^{16}$ which shows that the amount of time spent not moving will increase the risk of cardiovascular disease for individuals with spinal cord injuries. ${ }^{16}$ Another study from Tremblay et al. $(2010)^{6}$ indicated that sedentary behaviour causes accelerated bone resorption without corresponding improvements in bone structure, resulting in decreased bone mineral content and an elevated risk of osteoporosis. This author, moreover, explained that the chances of becoming obese rose as weekly hours of TV viewing time increased in the 2007 Canadian Community Health Survey, which included 42,612 people. $^{6}$

According to Kadir (2009), ${ }^{17}$ when exercising exceeds the target heart rate of the maximum heart rate, it will cause health problems and can even lead to sudden death and rupture of heart blood vessels. Meanwhile, the target heart rate achieved sustainably will result in an adaptation process to the cardiovascular system, such as preventing tissue damage, increasing blood volume and haemoglobin and preventing the risk of cardiovascular disease. A study by Neufeld et al. (2019) ${ }^{18}$ concluded a greater increase by paying attention to train time from the exercise zone with target heart rate, which shows the importance of doing this in improving fitness. Based on Achten and Jeukendrup (2003), ${ }^{19}$ there is a linear relationship between heart rate and exercise intensity. Heart rate is an accurate means of assessing and monitoring the relative intensity of exercise.

\section{DISCUSSION}

Exercise is thought to increase susceptibility to infection, but only in vigorous exercise. Some people have died on the sports field due to heart attacks.4 Exercise dosage is different for each age and individual physical condition. ${ }^{9}$ Regular exercise is useful in reducing and preventing the effects of sedentary and other chronic diseases and can increase immunity. Increased body immunity due to stimulation of the exchange of innate immune system cells and components between lymphoid tissue and blood. This stimulation will increase immune-surveillance against pathogens accompanied by a decrease in systemicinflammation such as IL-6, complement and immunoglobulin. ${ }^{20}$

Several studies have found that physical exercise of high intensity and long duration can have adverse effects. Heavy exercise loads, competition, physiological, psychological and metabolic stresses are associated with immune dysfunction, inflammation, oxidative stress and muscle damage. There is a change in immune cell function in the hours to days after exposure to physical activity with heavy and prolonged intensity. This system change occurs in various compartments of the body's immune system, including the mucosal tissue of the upper respiratory tract and lungs. ${ }^{20}$ Moreover, the exercises that can optimize the work of the heart, blood vessels and lungs in transporting oxygen so that the burning process of energy sources from 
carbohydrates and fat can run perfectly and can even increase the body's immune system. ${ }^{10}$

The maximal heart rate can measure the intensity. Maximum heart rate ( $\mathrm{HR} \max$ ) is the heart rate that can be reached during exercise and depending on age. The HR max can be estimated using several formulas. The most commonly used formulas are HR $\max =220$ - age (men), HR max = 226 - age (women), and HR $\max =220$ - half age (in obesity). ${ }^{21}$

Target Heart Rate (THR) is the value of the heart rate you want to achieve during exercise, which allows your heart and lungs to accept the load from the exercise you are doing. THR depends on a person's physical condition, gender and the intensity of the exercise done. The American College and Sports Medicine (ACSM) ${ }^{19}$ defines the Karvonen method as a standard THR measurement for all forms of sports activity. The intensity is divided into Zone I with an intensity of 50\%-60\% HR max for heating and daily activities. Zone II (moderate-intensity exercise) with an intensity of 60\%-70\% HR max activities burn more calories than Zone I, such as brisk walking and strength training. Zone III (vigorous intensity) intensity of 70\%-80\% HR max consists of activities or exercises for endurance, for example, jogging or race walking. Zone IV (anaerobic zone) or so-called threshold zone with an intensity of $80 \%-90 \% \mathrm{HR}$ max. Zone $\mathrm{V}$ with an intensity of $90 \%-100 \% \mathrm{HR}$ max is a red line zone, where most people cannot reach this zone only professional athletes. ${ }^{22}$ The research of Savonen et al. $(2006)^{23}$ demonstrated that increased heart rate during exercise might increase mortality in cardiovascular disease due to an increase in heart rate beyond the maximum heart rate. Because of the link between physical exercise, resting heart rate, and overall health. Resting heart rate is usually assessed as an indicator of health and used to assess various heart diseases. ${ }^{24}$

\section{CONCLUSION}

The sedentary lifestyle causes various health problems such as obesity, decreased bone mineral density, cardiovascular disease, metabolic diseases, cancer, and psychosocial problems. Appropriate exercise is a way to overcome the problems of the sedentary effect. However, it is necessary to pay attention to health and fitness goals. THR can help to exercise more safely while improving health status. Further research is needed to see the effect of applying the THR to improve the wider community's health.

\section{CONFLICT OF INTEREST}

We do not have any conflict of interest.

\section{FUNDING}

N/A

\section{AUTHOR CONTRIBUTIONS}

AAGESU conceived the study design, searched the literature, and drafted the manuscript; MW and IPYP searched the literature and drafted the manuscript.

\section{REFERENCES}

1. Dutheil F, Baker JS, Navel V. COVID-19 as a factor influencing air pollution? Environ Pollut. 2020;263:114466.

2. Chan JF-W, Yuan S, Kok K-H, To KK-W, Chu H, Yang J, et al. A familial cluster of pneumonia associated with the 2019 novel coronavirus indicating personto-person transmission: a study of a family cluster. The lancet. 2020;395(10223):514-23.

3. Djalante R, Lassa J, Setiamarga D, Sudjatma A, Indrawan $\mathrm{M}$, Haryanto B, et al. Review and analysis of current responses to COVID-19 in Indonesia: Period of January to March 2020. Progress in Disaster Science. 2020;6:100091.

4. Yuliana Y. Olahraga yang Aman di Masa Pandemi COVID-19 untuk Meningkatkan Imunitas Tubuh. Jurnal Bali Membangun Bali.1(2):103-10.

5. Puspasari I, Sulchan M, Widyastuti N. Sedentary Lifestyle Sebagai Faktor Risiko Terhadap Kejadian Obesitas Anak Stunted Usia 9-12 Tahun Di Kota Semarang: Diponegoro University; 2017.

6. Tremblay MS, Colley RC, Saunders TJ, Healy GN, Owen N. Physiological and health implications of a sedentary lifestyle. Applied physiology, nutrition, and metabolism. 2010;35(6):725-40.

7. López VF, Rodríguez GP, García CE, Pérez SJ. Relationship between sport and physical activity and alcohol consumption among adolescents students in Murcia (Spain). Arch Argent Pediatr. 2016;114(2):101.

8. Halabchi F, Ahmadinejad Z, Selk-Ghaffari M. COVID-19 epidemic: exercise or not to exercise; that is the question. Asian J Sports Med. 2020;11(1):e102630.

9. Malm C, Jakobsson J, Isaksson A. Physical activity and sports-real health benefits: a review with insight into the public health of Sweden. Sports. 2019;7(5):127.

10. Zhu N, Zhang D, Wang W, Li X, Yang B, Song J, et al. A novel coronavirus from patients with pneumonia in China, 2019. N Engl J Med. 2020.

11. Burke E. Precision heart rate training: Human Kinetics; 1998. 
12. Zheng C, Huang WY, Sheridan S, Sit CH-P, Chen $\mathrm{X}-\mathrm{K}$, Wong SH-S. COVID-19 pandemic brings a sedentary lifestyle in young adults: a cross-sectional and longitudinal study. Int J Environ Res Public Health. 2020;17(17):6035.

13. Carson V, Wong SL, Winkler E, Healy GN, Colley RC, Tremblay MS. Patterns of sedentary time and cardiometabolic risk among Canadian adults. Prev Med. 2014;65:23-7.

14. Lesser IA, Nienhuis CP. The impact of COVID-19 on physical activity behavior and well-being of Canadians. Int J Environ Res Public Health. 2020;17(11):3899.

15. Hamburg NM, McMackin CJ, Huang AL, Shenouda SM, Widlansky ME, Schulz E, et al. Physical inactivity rapidly induces insulin resistance and microvascular dysfunction in healthy volunteers. Arterioscler Thromb Vasc Biol. 2007;27(12):2650-6.

16. Bauman W, Spungen A. Coronary heart disease in individuals with spinal cord injury: assessment of risk factors. Spinal Cord. 2008;46(7):466-76.

17. König D, Grathwohl D, Weinstock C, Northoff H, Berg A. Upper respiratory tract infection in athletes: influence of lifestyle, type of sport, training effort, and immunostimulant intake. Exerc Immunol Rev. 2000;6:102-20.

18. Kadir A. Adaptasi Kardiovaskular Terhadap Latihan Fisik. Jurnal Ilmiah Kedokteran Wijaya Kusuma. 2009(Khusus):37-47.
19. Juul A, Jeukendrup A. Heart rate monitoring: Applications and limitations. Sport Medicine. 2003;33:517Á38.

20. Neufeld EV, Wadowski J, Boland DM, Dolezal BA, Cooper CB. Heart rate acquisition and thresholdbased training increases oxygen uptake at metabolic threshold in triathletes: a pilot study. International journal of exercise science. 2019;12(2):144.

21. Nieman DC, Wentz LM. The compelling link between physical activity and the body's defense system. Journal of sport and health science. 2019;8(3):201-17.

22. Hillman $\mathrm{CH}$, Logan NE, Shigeta TT. A review of acute physical activity effects on brain and cognition in children. Translational Journal of the American College of Sports Medicine. 2019;4(17):132-6.

23. Sylta $\varnothing$, Tønnessen E, Seiler S. From heart-rate data to training quantification: a comparison of 3 methods of training-intensity analysis. Int J Sports Physiol Perform. 2014;9(1):100-7.

24. Savonen KP, Lakka TA, Laukkanen JA, Halonen PM, Rauramaa TH, Salonen JT, et al. Heart rate response during exercise test and cardiovascular mortality in middle-aged men. Eur Heart J. 2006;27(5):582-8.

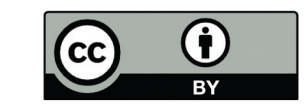

This work is licensed under a Creative Commons Attribution 